INTERNATIONAL JOURNAL OF
ORGANIZATIONAL LEADERSHIP
ORGANIZATIONAL
LEADERSHIP

\title{
Examining the Role of Motivation and Reward in Employees' Job Performance through Mediating Effect of Job Satisfaction: An Empirical Evidence
}

\author{
Kalpina Kumari ${ }^{1}$, Salima Barkat Ali $^{2}$, Noor un Nisa Khan ${ }^{3}$, Jawad Abbas ${ }^{4}$ \\ ${ }^{1}$ Faculty of Department of Business Administration, Greenwich University of Karachi, Pakistan \\ ${ }^{2}$ Faculty of Department of Psychology, Iqra University of Karachi, Pakistan \\ ${ }^{3}$ Faculty of Department of Business Administration, Iqra University of Karachi, Pakistan \\ ${ }^{4}$ Faculty of Management Sciences, University of Central Punjab, Lahore, Pakistan
}

Keywords:

Rewards, Motivation, Job satisfaction, Job performance

Received

09 October 2021

Received in revised form

16 November 2021

Accepted

21 November 2021

*Correspondence

jawad.abbas@ymail.com

\begin{abstract}
The current research uses the principles of reinforcement theory of motivation and selfdetermination theory and investigates how motivation and rewards impact on job performance of employees. Motivation and rewards are examined from intrinsic and extrinsic perspectives, while job performance is measured from the task and contextual performance aspects. The mediating effect of job satisfaction has also been investigated between motivation, rewards, and job performance. Using five points Likert scale, the researchers collected data from the managerial and non-managerial staff working in manufacturing and services firms. Non- probability convenience sampling technique was followed to collect 422 empirical responses. The collected data were analyzed using the structural equation modeling technique. The results indicated that reward and motivation affect employee job performance positively significantly. However, the dimensional analysis indicated an insignificant impact of intrinsic and extrinsic motivation on contextual performance. Besides, the findings substantiate that the relationship between rewards, motivation, and employees' job performance depends on job satisfaction. The current research provides valuable insights to senior management of manufacturing and services firms on how they can enhance their employees' job satisfaction and performance by following different motivational and reward approaches in different size firms.
\end{abstract}


Businesses face evolving challenges in the current dynamic market scenario (Din, Shahani, \& Baloch, 2021). Some of these challenges are volatile social and economic conditions, such as the COVID-19 pandemic (Habib, Abbas, \& Noman, 2019), global business competition caused by technological changes (such as the internet), changing customers' needs, competitive industry nature, etc. (Baughman, 2018). Firms can achieve their strategic goals only if they maintain the highest quality in operations and customer service. Such initiatives will enhance organizational performance (Guilbault, 2018) and facilitate them to achieve a competitive advantage (Jeni, Mutsuddi, \& Das, 2020). Organizational performance is a multi-faceted concept that relies on multiple elements, such as financial situation, infrastructure, service quality, etc. (Anwar \& Abdullah, 2021). However, human resource (HR) is the most important among all the available resources since it has great potential to variate a firm's overall performance (Abbas et al., 2021). According to Tian et al. (2021), the strength of an organization is determined by the quality of its workforce. Therefore, the highly competitive industrial situation is compelling employers to recruit and retain competent and talented employees for their company (Abbas \& Sagsan, 2019). They can follow and do justice to firms' stated mission with more effectiveness (Hamza et al., 2021). For this reason, retaining welltrained employees who have relevant experience and are open to taking responsibilities is one of the most important concerns, as they directly affect the performance of an organization.

Employees' performance plays a critical role in the success or failure of any firm (Yang \& $\mathrm{Ai}, 2020)$. With the emergence of the COVID-19 pandemic, in particular, most firms have faced economic downfall and, at the same time, the performance and motivation level of employees have also deteriorated (Aguinis \& Burgi-Tian, 2021). For this reason, firms must identify means to bring out the best performance from their employees (Bao et al., 2021). In simple words, employee performance refers to how they perform the assigned duties and tasks, including results and the behavior that they demonstrate while performing their tasks (Abbas \& Sagsan, 2019). Dynamic firms take employee performance as a driving force for their success and continuously work to ensure their improvement (Jeni et al., 2020). Performance can be measured on quantity, quality, and/or work efficiency (Tian et al., 2021). In addition, multiple factors influence employee performance, such as infrastructure and facilities, workplace environment (Bao et al., 2021), job satisfaction, relationship with colleagues, etc. (Nguyen et al., 2020). Motivation is another factor that can play a significant role in their performance (Abbas \& Kumari, 2021).

From an organizational perspective, motivation is a process that stimulates employees to act to achieve organizational goals (Prasetiyani et al., 2021). According to Yang and Ai (2020), employee motivation has two sources, namely intrinsic and extrinsic. Extrinsic motivation can be attributed to factors in the workplace, whereas intrinsic motivation is an inner driving force that propels you to achieve more (Mazllami, 2020). Likewise, well-rewarded employees feel that the organization is valuing them. If an employer takes care of the employee and rewards them for appreciating their work, in return, the employee will put maximum effort to achieve his defined targets (Jeni, Mutsuddi, \& Das, 2020). The absence of a motivation and rewards system reduces workers' morale (Hammond \& Waltemeyer, 2021). Similarly, Shaikh, Shaikh, and Shaikh (2019) stated that firms with poor motivation and reward systems experience higher high turnover. 
The current study bases its arguments on the reinforcement theory of motivation and selfdetermination. It investigates the role of motivation and reward systems in employee job performance, specifically task and contextual performance. It also investigates the relationship between motivation, reward, and employee job satisfaction and if employee job satisfaction mediates the relation between motivation, reward, and employee job performance. Therefore, the current research is designed to answer the following queries:

RQ1: Do intrinsic and extrinsic motivation impact employees' task and contextual performance?

RQ2: Do intrinsic and extrinsic rewards systems within an organization impact employees' task and contextual performance?

RQ3: Does job satisfaction mediates the relationship between rewards, motivation, and employee's job performance?

The findings of this study will benefit industrialists and academicians. It will help to understand how different motivation and reward orientations can help employees achieve desirable results. Workers can have different motivational orientations contingent on their needs, leading to their job attitude, behavior, and overall performance. For this reason, while designing their human resource strategy, managers must understand employees' different needs. Given the multidimensional nature of motivation, reward, job satisfaction, and employee performance, this study differentiates their impact at the individual and dimensional levels to identify the link between these orientations. This study will also validate some previous studies that have studied the role of motivation and reward in employee performance in individual or conjointly format.

\section{Theory and Literature}

Every organization has certain goals and objectives to achieve. These objectives are met with the help of capital, raw materials, infrastructure and facilities, human resources, etc. (Tajeddini, Martin, \& Altinay, 2020). For any organization, human asset and their performance at the workplace tops the list of resources needed to achieve its defined objectives (Kazmi \& Abbas, 2021). According to Campbell and Wiernik (2015), employee job performance refers to certain behavioral patterns and outcomes that can be observed and analyzed against specific standards put together by an organization based on its all-embracing goals. Hosie and Nankervis (2016) proposed a traditional dimensional model and structure that broke down job performance into contextual and task performance. When we talk about task performance, it encompasses individual behaviors while performing their defined roles. On the other side, contextual performance considers the interpersonal relationship that the people forge voluntarily to help perform the task, which boosts the organization's effectiveness (Imran \& Abbas, 2020).

The current study integrates the reinforcement theory of motivation and self-determination to investigate determinants of employees' job performance. The reinforcement theory of motivation was proposed by Skinner (2014) and stated that behavior is influenced by its consequences. Furthermore, as the reinforcement theory suggests, someone's behavior can be changed by using punishment and reinforcement. Rewards can be used to reinforce and promote the desired and positive behavior, while punishments can be used to prevent the undesired behavior. Self-determination theory (SDT), presented by Deci and Ryan (1985), explained that self-motivation is a result of individuals who are self-driven and encouraged to keep a check on 
how they behave (Ryan \& Deci, 2020). From the given explanation of both theories, it can be concluded that the reinforcement theory of motivation deals majorly with extrinsic factors in terms of rewards and other motivational tactics to keep the employee motivated. In contrast, self-determination theory (SDT) is concerned with employees' intrinsic and self-driving motivation aspects. The conceptual model of this study is based on these two theories and states that employee motivation and organizational reward system are directly associated with employee job satisfaction and performance. Therefore, the combination of reinforcement theory of motivation and self-determination theory to investigate an underlying mechanism of determinants that can enhance employees' job performance at the workplace will contribute to both theory and practice (see Figure 1).

\section{Motivation and Employees' Job Performance}

Motivation is a commonly used word derived from the word "motive," having different meanings, such as a person's desires, needs, wants, and drives (Badura et al., 2020). It is the process of stimulating people to take the right actions to reach their goals or targets (Liu et al., 2021). Employee motivation is broadly categorized into two forms, i.e., extrinsic and intrinsic motivation. Behavior dictated by internal attitudes and motivated by internal rewards is classified as 'intrinsic motivation.' Also, alternatively known as "motivators" or "satisfiers." These factors also serve as an additional source of increased employee job satisfaction (Catharina \& Victoria, 2015). These intrinsic factors include a sense of achievement, responsibility, personal growth, recognition, and work itself. On the contrary, forces that are present in the external environment connected to your working environment are known as extrinsic factors. These extrinsic motivators are also called "hygiene" or "dissatisfaction avoidance." Ghazi, Shahzada, and Khan (2013) established that the absence of these hygiene factors can decrease motivation although they cannot guarantee satisfaction.

According to Nyinyimbe (2020), motivation is an ideal tool for achieving employees' superior performance at the workplace, leading towards organizational effectiveness. Aizza et al. (2018) indicated that intrinsic and extrinsic motivational factors play a critical role in building a long-term relationship with employees. Triswanto and Yunita (2021) have also reported similar results, who stated that both intrinsic and extrinsic motivation has a positive and significant effect on employees' output. In the "Human Motivation" theory, Maslow (1943) identified different factors that impact human motivation. He classified those factors into physiological, safety, social recognition, self-esteem, and self-actualization needs. Therefore, from an organizational perspective, HR managers must design and execute diverse motivational strategies to positively cater to the different needs of their personnel at the workplace (Gift \& Obindah, 2020).

Saengchai, Siriattakul, and Jermsittiparsert (2019) argued that their enhanced enthusiasm would naturally improve productivity when employees feel motivated and competent. Consequently, employee motivation is dominant in determining the success of any organization and ensures that work continues smoothly without any hindrances and in a proficient manner (Ahsan, Nasir, \& Abbas, 2020; Zainal, 2017). In their study, Yousaf, Yang, and Sander (2015) examined the role of employees' intrinsic and extrinsic motivation in their task and contextual performance and identified that task and contextual performance were positively affected by extrinsic motivation. However, they identified an insignificant relationship between intrinsic 
motivation and contextual performance. Guo and Ling (2020) studied if leaders' motivating language impacts employees' task and contextual performance and identified a positive relationship between them.

The literature provides contradictory findings on the relationship between motivation and employee performance, particularly at the dimensional level. Thus, it warrants further clarification. For this purpose, the following hypotheses are proposed:

$\mathrm{H}_{1}$ : Employees' motivation to work is positively associated with their job performance.

$\mathrm{H}_{1 \mathrm{a}}$ : Employees' motivation to work is positively associated with their task performance.

$\mathrm{H}_{1 \mathrm{~b}}$ : Employees' motivation to work is positively associated with their contextual performance.

$\mathrm{H}_{1 \mathrm{c}}$ : Employee extrinsic motivation positively predicts employees' job performance.

$\mathrm{H}_{1 \mathrm{~d}}$ : Employee extrinsic motivation positively predicts employees' task performance.

$\mathrm{H}_{1 \mathrm{e}}$ : Employee extrinsic motivation positively predicts employees' contextual performance.

$\mathrm{H}_{1 \mathrm{f}}$ : Employee intrinsic motivation positively predicts employees' job performance.

$\mathrm{H}_{1 \mathrm{~g}}$ : Employee intrinsic motivation positively predicts employees' task performance.

$\mathrm{H}_{1 \mathrm{~h}}$ : Employee intrinsic motivation positively predicts employees' contextual performance.

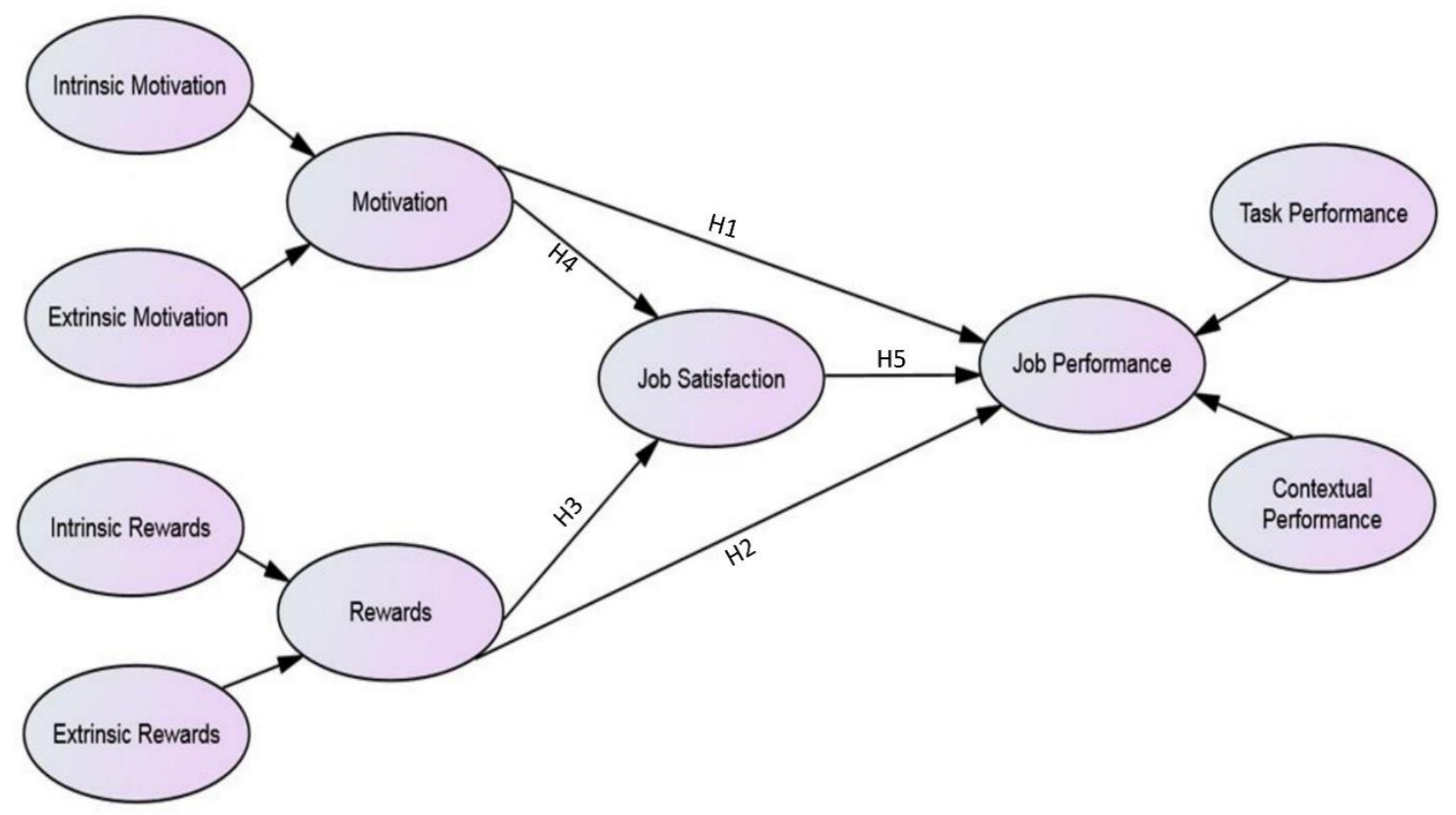

Figure 1. Conceptual framework

\section{Rewards and Employees' Job Performance}

In Social exchange theory, Blau (1964) stated that employees owe their loyalty to a great extent to the organization when their financial needs are met in the form of rewards. Hence, it can be said that employees' retention and performance are directly proportional to the number and quality of rewards the organization offers. Therefore, the reward is a focal point of the employment relationship. Willsen (2020) classified rewards into two broad categories: monetary and non-monetary. Monetary rewards generally include cash awards, commission, bonuses, etc., while non-monetary rewards include flexible timing, childcare, mentoring programs, medical or education assistance, etc. Both types can be utilized to enhance employees' behavior and performance. However, organizational rewards were later divided into 
two principal forms: extrinsic and intrinsic (Alhmoud \& Rjoub, 2020). Extrinsic rewards consider tangible benefits like career development, promotion, varied growth opportunities, monetary compensation, and work-life balance (Sureephong et al., 2020). On the other hand, intrinsic rewards are immaterial because they are more related to the satisfaction that comes with one's responsibilities and co-workers' support (Hidayat, 2019).

Employers look for superior strategies to boost the morale of their employees to reach optimum level performance (Yousuf \& Siddiqui, 2019). However, employee performance is a multi-faceted phenomenon. It can be influenced by several factors such as training and development, working conditions, job security, worker and employer relationship, company's rules, policies to reward employees, etc. (Shakoor, Fakhar, \& Abbas, 2021). Considering all these factors, employee performance is affected by the motivation factor that follows rewards and ultimately plays a significant role in enhancing workplace productivity (Koralege \& Priyashantha, 2019).

The sum of financial and non-financial rewards plays a pivotal role in retaining employees at any firm. This further leads to increased productivity (Prasetiyani et al., 2021). This means that if employees are adequately rewarded for their efforts, they will stay longer and work with the utmost dedication and commitment (Ngwa et al., 2019). Moreover, when employees feel valued and acknowledged for their efforts, they strive to surpass their managers' expectations with the anticipation that they will be well rewarded for their smart work (Admassie, 2019). It also serves as a source of inspiration for employees to continuously strive towards excellence (Fanggidae, Nursiani, \& Bengngu, 2019). Parashakti and Ekhsan (2020) stated that the targeted level of performance could only be achieved if the employee feels a sense of mutual trust, respect, and attainment of certain personal objectives. Hence, dynamic organizations used to have an effective reward and recognition program to boost staff morale and motivation, which led to organizational effectiveness in the long run (Hussain et al., 2019).

Rehman, Ilyas, and Saqib (2017) studied the role of extrinsic and intrinsic rewards in employees' job performance and found a positive association between them. Shaikh et al. (2019) also studied the matching model and found similar results. However, Özutku (2019) identified an insignificant relationship between intrinsic, extrinsic rewards and employee performance in Turkish manufacturing firms. Based on differences in the literature, this research aims to find a more specific and clear answer to the role of extrinsic and intrinsic rewards in employee performance. Thus, the following hypotheses are proposed:

$\mathrm{H}_{2}$ : Effective reward system positively predicts employees' job performance.

$\mathrm{H}_{2 \mathrm{a}}$ : Effective reward system positively predicts employees' task performance.

$\mathrm{H}_{2 \mathrm{~b}}$ : Effective reward system positively predicts employees' contextual performance.

$\mathrm{H}_{2 \mathrm{c}}$ : Extrinsic rewards system positively predicts employees' job performance.

$\mathrm{H}_{2 \mathrm{~d}}$ : Extrinsic rewards system positively predicts employees' task performance.

$\mathrm{H}_{2 \mathrm{e}}$ : Extrinsic rewards system positively predicts employees' contextual performance.

$\mathrm{H}_{2 \mathrm{f}}$ : Intrinsic rewards system positively predicts employees' job performance.

$\mathrm{H}_{2 \mathrm{~g}}$ : Intrinsic rewards system positively predict employees' task performance.

$\mathrm{H}_{2 \mathrm{~h}}$ : Intrinsic rewards system positively predicts employees' contextual performance. 


\section{Rewards and Job Satisfaction}

According to Ayub and Rafif (2011), the degree to which people like or dislike their jobs is known as job satisfaction. Job satisfaction is a positive emotional state derived from appraisals of one's job or the experience of the job itself (Kumar \& Singh, 2011). From an organizational perspective, job satisfaction plays an enormous role in ensuring a greater level of organizational commitment, ensuring the success of the entire organization and its development. Nazir et al. (2016) stated that rewards play an indispensable role in encouraging employees to stay committed, which leads to greater job pleasure among employees. Higher workforce consistency and higher standards of performance are sure to follow through. Rewards are important factors in ensuring job loyalty, and it is positively associated with employees' motivation at the workplace (Zafar et al., 2014). When employees achieve job satisfaction, the overall organization performance will likely be improved (Ouedraogo \& Leclerc, 2013).

In 1964, Herzberg introduced motivation-hygiene theory (also known as two-factor theory) and stated that two factors at the workplace affect employee job satisfaction, i.e., motivation and hygiene. Motivation refers to a worker's eagerness to work better. The other aspect is hygiene. This aspect will not push workers to perform harder, but their absence will demotivate workers. Herzberg mentioned salary as a hygiene factor responsible for eradicating job dissatisfaction and falls under extrinsic factors. From an organizational perspective, this research takes reward as the hygiene factor and states that if a firm does not adequately reward its employees, it will negatively affect their satisfaction level. Therefore, based on the above discussion, the given hypotheses are suggested:

$\mathrm{H}_{3}$ : Rewards positively impact employees' job satisfaction.

$\mathrm{H}_{3 \mathrm{a}}$ : Extrinsic rewards positively impact employees' job satisfaction.

$\mathrm{H}_{3 \mathrm{~b}}$ : Intrinsic rewards positively impact employees' job satisfaction.

\section{Motivation and Job Satisfaction}

According to Febrianti and SE (2020), increasing employee morale and job satisfaction are the key organizational concerns in the current era. Different motivation theories enlighten and educate us about employees' motivation and job satisfaction, for example, process, need-based, and reinforcement theories. Ali and Anwar (2021) established that although motivation and job satisfaction are dependent terms, they cannot be used interchangeably. The motivational process considers job satisfaction an important facet (Safdar et al., 2020). While motivation helps give us direction and stay consistent on our goals, job satisfaction empowers us with a sense of accomplishment through different work-related activities and rewards.

Paais and Pattiruhu (2020) stated that the extent of job satisfaction is dependent on both intrinsic and extrinsic motivational factors. Bayraktar et al. (2017) stated that intrinsic motivation plays a vital role in affecting employees' association with the company. Employees' higher intrinsic motivation can be linked with higher employees' loyalty and vice versa. Alshmemri, Shahwan-Akl, and Maude (2017) reported that intrinsic factors lead towards greater employee motivation and promote job commitment at the workplace. From an extrinsic motivation perspective, Catharina and Victoria (2015) cited job security to be one of the most integral extrinsic factors which have a considerable impression on employees' job satisfaction. Moreover, compensation, including salary and fringe benefits, also directly impacts employees' job satisfaction. However, a study by Breaugh, Ritz, and Alfes (2018) reported an insignificant 
relationship between intrinsic motivation and job satisfaction. The existing literature presents contradictory and inconsistent data on the relationship between motivation and job satisfaction. To cover this issue holistically, the following hypotheses have been proposed:

$\mathrm{H}_{4}$ : Motivation positively impacts employees' job satisfaction.

$\mathrm{H}_{4 \mathrm{a}}$ : Extrinsic motivation positively impacts employees' job satisfaction.

$\mathrm{H}_{4 \mathrm{~b}}$ : Intrinsic motivation positively impacts employees' job satisfaction.

\section{Job Satisfaction and Employees' Job performance}

In the past literature, job satisfaction has received the attention of many researchers since most of them believe that it plays an important role in an individual's performance within the organization (Mohammad et al., 2017). Generally, it is believed that a happy worker is more likely to be a productive worker. However, the review of the literature indicates contradictory findings on the link between job satisfaction and employee job performance. For instance, the study of Brayfield and Crockett (1955) is among the most prominent that highlighted the insignificant correlation between employee job satisfaction and their job performance. Hünefeld, Gerstenberg, and Hüffmeier (2020) also indicated that job satisfaction was not meaningfully associated with job performance and labeled it as minimal or no relationship. The study by Alsafadi and Altahat (2021) also reported a similar insignificant relationship between the relationship of the said variables.

On the other hand, several studies have publicized that job satisfaction is strongly linked with employees' job performance. For example, Idris et al. (2020) posited that job satisfaction creates happiness and enhances morale and employee motivation, leading to increased productivity. Wolomasi, Asaloei, and Werang (2019) concluded that satisfied employees who held positive feelings toward their work tend to perform their duties better. Al-Ali et al. (2019) asserted that a satisfied employee performs his duties more creatively. Given the inconsistent findings on the relationship between job satisfaction and job performance, this study examines the direct association between job satisfaction and employee performance. This study also takes job satisfaction as the intervening variable and investigates whether it mediates the relationship between motivation, reward, and job performance or not. Thus, the following hypotheses are proposed:

$\mathrm{H}_{5}$ : Job satisfaction positively impacts employees' job performance.

$\mathrm{H}_{5 \mathrm{a}}$ : Job satisfaction positively impacts employees' task performance.

$\mathrm{H}_{5 \mathrm{~b}}$ : Job satisfaction positively impacts employees' contextual performance.

$\mathrm{H}_{6}$ : Job satisfaction mediates the relationship between rewards and employees' job performance.

$\mathrm{H}_{7}$ : Job satisfaction mediates the relationship between motivation and employees' job performance.

\section{Method}

\section{Target population}

Since the current research focuses on services and manufacturing industries, the target population includes all the managerial and non-managerial employees working in manufacturing and services firms located within Karachi, Lahore, and Islamabad cities of Pakistan. The reason behind choosing these three cities is that these cities are believed as the 
major business venues of Pakistan. In addition, these cities also constitute a diverse array of people from different cultural backgrounds, representing our targeted population in the best possible way.

\section{Sampling Procedure}

The ideal sample size for conclusive research would be 30 to 500 samples or 10 times or more than the number of items that are each assigned a variable which is dependent, independent, moderating, mediating, and control variables (Sekaran \& Bougie, 2003). The authors distributed 652 questionnaires to the managerial and non-managerial staff working in manufacturing and services firms in our target cities. At first hand, only 292 filled questionnaires were returned after two weeks. To collect the data from the remaining respondents, the soft reminders were sent, and 130 more responses were received; so, the total number of returned questionnaires was 422 . The response rate recorded is an indirect measure of how the respondents rate the questionnaire in terms of relevancy and rigor. When respondents perceive that a particular study holds significance and deserves their attention, they are more likely to return a questionnaire.

The given response rate indirectly indicates the coherence and accuracy of the questionnaire. The study's importance and dependency on its respondents motivate the volunteers to return the questionnaires.

To approach the target population and collect their responses, the authors followed the nonprobability convenience sampling technique because of the inaccessibility of the whole population (Kumar, 1996). The detailed demographic information of respondents is presented in Table 1.

Table 1

Demographics of the Respondents

\begin{tabular}{llcc}
\hline \multicolumn{1}{c}{ Particulars } & Description & Values & Percentage \\
\hline Total Responses & Manufacturing & 173 & $41 \%$ \\
\multirow{3}{*}{ Gender } & Services & 249 & $59 \%$ \\
& Female & 215 & $51 \%$ \\
& Male & 207 & $49 \%$ \\
Age & Prefer not to say & 4 & $1 \%$ \\
& Less than 20 & 135 & $32 \%$ \\
& $20-30$ & 203 & $48 \%$ \\
& $31-40$ & 59 & $14 \%$ \\
Years of experience & $41-50$ & 8 & $2 \%$ \\
& $50+$ & 13 & $3 \%$ \\
& Less than 5 & 131 & $31 \%$ \\
& $5-10$ & 207 & $49 \%$ \\
Position within the organization & $11-15$ & 68 & $16 \%$ \\
& $16-20$ & 6 & $1.50 \%$ \\
& More than 20 & 11 & $2.60 \%$ \\
& Operational staff & 165 & $39 \%$ \\
Organizational status & Junior management & 152 & $36 \%$ \\
& Middle management & 97 & $23 \%$ \\
& Top management & 9 & $2.08 \%$ \\
& Public & 194 & $46 \%$ \\
\hline
\end{tabular}

\section{Data Collection}

The authors followed a self-administered questionnaire technique to collect the data. The researchers also had a detailed face-to-face discussion with some respondents to get unbiased and reliable data. They explained to the respondents the purpose of the study and guided them 
on how to fill out the questionnaire. The participants were given the assurance of confidentiality of all their responses.

\section{Description of Measures}

To collect the empirical data, the researchers used a five-point Likert scale, in which one suggested strongly disagree and five suggested strongly agree. The questionnaire listed five parts: the first part contained information about the demographics of the participants, followed by measures for intrinsic and extrinsic rewards, intrinsic and extrinsic motivation, job satisfaction along with task, and contextual performance. Motivation, including intrinsic and extrinsic, was measured using 13 items taken from Mikander's (2010) study. Rewards, including intrinsic and extrinsic, were measured using 12 items. The items were extracted from Muchiri's (2016) and Ibrar and Khan's (2015) studies. Six items extracted from Mikander's (2010) research measured job satisfaction. Finally, task and contextual performance were measured using eleven items developed by Omokorede and Olufunke (2017).

As Hinkin (1998a) recommended, the authors conducted a pilot study by collecting responses from 40 employees to ensure that the adopted instrument is reliable and valid. The primary results indicated the internal consistency of the constructs and showed values in the range of .79 to .91 and adequately complied with Hair et al.'s (2012) minimum suggested value of .70 .

\section{Data Analysis and Results}

The researcher used the SEM technique to analyze the correlation between rewards, motivation, job satisfaction, and employees' job performance. The researchers used SPSS v.23 and Amos v. 23 to conduct the structural and empirical analyses. It has the strength to create a latent structure hierarchy and eliminate the biases caused by measuring errors (Prajogo \& Cooper, 2010). The researchers tested the sample size appropriateness through the Kaiser-Meyer-Olkin test, which showed .83 . This value fulfills the minimum requirement of .6 proposed by Kaiser and Rice (1974). The multi-collinearity factor was analyzed through the variance inflation factor (VIF), showing a value of 3.01. This value fulfills the requirement of Hair et al. (2010) where the value of less than 4 indicates the absence of multi-collinearity. As per Podsakoff, MacKenzie, and Podsakoff (2012), common method bias (CMB) affects the results when a single factor accounts for more than $50 \%$ of the overall variance. The authors performed Harman's single factor test to analyze CMB. The result indicated a value of $36.44 \%$ which is sufficiently below the threshold value of $50 \%$ indicating the non-existent data of CMB.

\section{Assessment of the Measurement and Structural Model}

The researchers performed the confirmatory factor analysis (CFA) to examine the measurement model. According to Hinkin (1998a), CFA confirms the accuracy of the measurement process and its uni-dimensionality. The consistency of the measures was assessed via Cronbach's alpha and indicated a value of .89. This met the required value of .80 suggested by Peterson (1994) and indicated adequate reliability. The researcher tested cogency by employing the convergent and discriminant validity tests. Awang (2012) and Hair et al. (2010) explained that convergent validity could be evaluated by factor loading. According to Awang (2012), the ideal loading for already established items is above .60. Moreover, according to Molina, Montes, and Moreno (2007), for all constructs, the lowest value of the extracted average variance explained (AVE) 
should be greater than .50 . The convergent validity result indicated loading items higher than .60 and AVE values higher than .50 for all constructs. Table 2 displays the description of loading products along with AVE values and the composite reliability of the constructs. The discriminant validity was assessed as guided by the criteria of Fornell and Larcker (1981) and Hair et al. (2010).

Table 2

Instrument Reliability and Validity

\begin{tabular}{|c|c|c|c|c|}
\hline Variable & Number of Items & Factor Loading & Composite Reliability & $\mathrm{AVE}^{\mathrm{b}}$ \\
\hline Intrinsic Reward & 4 & $.85-.91$ & .87 & .69 \\
\hline Extrinsic Reward & 4 & $.78-.89$ & .79 & .70 \\
\hline Reward & 4 & $.77-.82$ & .81 & .71 \\
\hline Intrinsic Motivation & 5 & $.62-.77$ & .79 & .69 \\
\hline Extrinsic Motivation & 4 & $.69-.83$ & .77 & .77 \\
\hline Motivation & 5 & $.73-.95$ & .87 & .67 \\
\hline Job Satisfaction & 5 & $.71-.92$ & .81 & .78 \\
\hline Task Performance & 5 & $.69-.92$ & .88 & .68 \\
\hline Contextual Performance & 5 & $.71-.89$ & .91 & .72 \\
\hline $\begin{array}{l}\text { Performance } \\
\text { Job Performance }\end{array}$ & 5 & $.69-.87$ & .88 & .78 \\
\hline
\end{tabular}

Note. a: The value of composite reliability should be $\geq .70$ (Molina, Montes, \& Moreno, 2007)

b: Average variance extracted (AVE) value should be $\geq .50$ (Molina, Montes, \& Moreno, 2007)

Table 3

Discriminant Validity Analysis

\begin{tabular}{lccc}
\hline Variable & Reward & Motivation & Job Satisfaction \\
\hline Reward & .83 & & Job Performance \\
Motivation & .52 & .83 & .58 \\
Job Satisfaction & .60 & .60 & .82 \\
Job Performance & .66 & .58 \\
\hline
\end{tabular}

Note. * Bold and italic values are AVE square root values for each construct

According to Kaynak (2003), seven indicators determine the fit of the measuring model, namely chi-square to a degree of freedom $\left(\mathrm{x}^{2} / \mathrm{df}\right)$, the goodness of fit index (GFI), normative fit index (NFI), adjusted goodness of fit index (AGFI) root mean square error of approximation (RMSEA) comparative fit index (CFI), and standardized root mean squared residual (SRMR). The researcher also incorporated the Tucker-Lewis index (TLI) to assure the assessment and performance of the structural model.

The findings showed that, for the measuring model, the $\mathrm{x}^{2} / \mathrm{df}$ value was 1.17 , which fulfills the requirement of less than three (Bagozzi \& Yi, 1988). The RMSEA value was .03, which is below the maximum value of .08 suggested by Browne and Cudeck (1992). The SRMR value was .05, meeting the .1 cut-off criterion suggested by Hu and Bentler (1998). Moreover, the values of GFI AGFI, CFI, NFI, and TLI are also above the ideal value of .9 suggested by Bagozzi and Yi (1988), Bentler and Bonett (1980), and Bollen (1986). The structural model analysis indicated an $\mathrm{x}^{2} / \mathrm{df}$ value of 1.18 . The RMSEA value was .04, and the SRMR value was .041 , which fully complies with the maximum values of .08 and .1 suggested by Browne and Cudeck (1992) and Hu and Bentler (1998), respectively. Finally, the values of NFI CFI, TLI, AGFI, and GFI were also above the ideal value of .9 recommended by Bagozzi and Yi (1988) and Bentler and Bonett (1980). Taking these findings into account, it can be assumed that both the measurement and the structural models align well with the data. Table 4 gives details of the measurement and structural models. 
Table 4

Analysis of Measurement and Structural Model

\begin{tabular}{lccllllll}
\hline Measures of Fit & $\mathrm{CMIN} \mathrm{DF}^{\mathrm{a}}$ & $\mathrm{NFI}^{\mathrm{b}}$ & $\mathrm{GFI}^{\mathrm{b}}$ & $\mathrm{AGFI}^{\mathrm{b}}$ & $\mathrm{CFI}^{\mathrm{b}}$ & $\mathrm{TLI}^{\mathrm{b}}$ & RMSEA $^{\mathrm{c}}$ & SRMR $^{\mathrm{d}}$ \\
\hline Recommended value & $\leq 3^{1}$ & $\geq .9^{2}$ & $\geq .9^{2}$ & $\geq .9^{2}$ & $\geq .9^{2}$ & $\geq .9^{2}$ & $\leq .08^{3}$ & $\leq .08^{4}$ \\
Measurement Model & 1.17 & .91 & .91 & .92 & .91 & .91 & .03 & .05 \\
Structural Model & 1.18 & .92 & .92 & .92 & .92 & .93 & .04 & .04 \\
\hline
\end{tabular}

Note. a (Bagozzi\& Yi, 1988); b (Bentler \& Bonett, 1980; McDonald \& Marsh, 1990); c (Browne \& Cudeck, 1992)

d (L. Hu and Bentler, 1998)

\section{Testing the Hypotheses}

As presented in Table 5, this study indicated that motivation had a significant positive impact on employee job performance, $\beta=.29, p=.01$, and led to the acceptance of $\mathrm{H}_{1}$, motivation positively impacts employee job performance. The path analysis also pointed out a significant positive impact of rewards on workers' job performance $\beta=.23, p=.01$. Hence, $\mathrm{H}_{2}$, rewards positively impact employees' job performance, is also accepted. The examination of the relationship between rewards and job satisfaction also specified a positive result $\beta=.29, p=$ .005. Hence, the $\mathrm{H}_{3}$, rewards positively impact employees' job satisfaction, is accepted. Similarly, the testing motivation and job satisfaction also presented significant positive results, $\beta=.26, p=.02$. Therefore, the $\mathrm{H}_{4}$, motivation positively impact employeeS' job satisfaction, is also accepted. Following this, the authors studied the effect of job satisfaction on employee job performance. The path analysis presented $\beta=.29, p=.003$. This significant finding directed the acceptance of $\mathrm{H}_{5}$, job satisfaction positively impact employee job performance (see Figure 2).

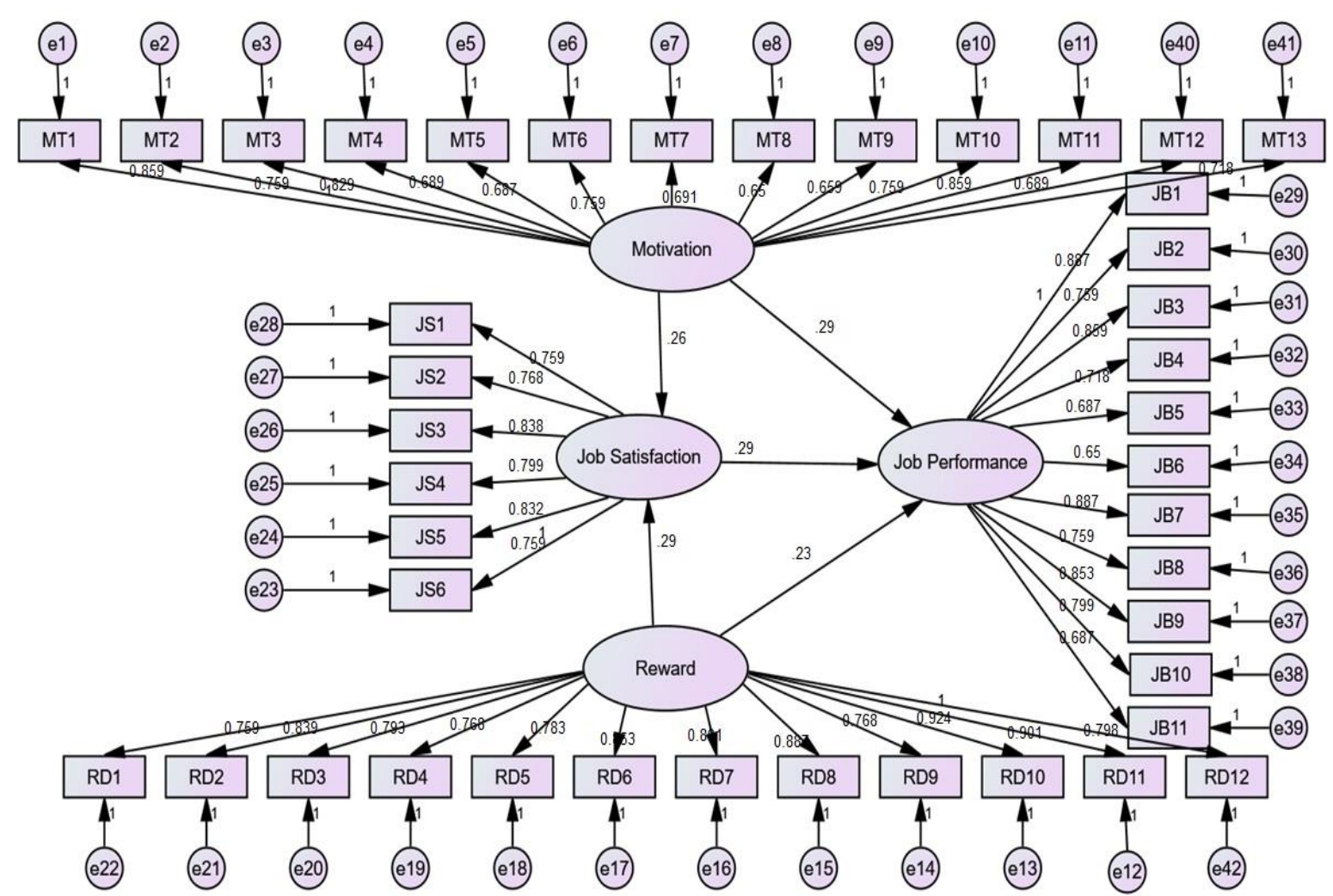

Figure 2. Structural model 
Finally, the authors examined the mediating role of job satisfaction. Firstly, job satisfaction was taken as a mediating variable between rewards and employee job performance. The inclusion of job satisfaction reduced the direct effect of rewards on job performance $\beta=.23$ to .21. This value is declined since a share of the effect has been transmitted through job satisfaction. However, since the result is still significant with a p-value of .03, the researchers concluded the partial mediation of job satisfaction on the correlation between reward and employee job performance, and $\mathrm{H}_{6}$ is accepted. Similarly, job satisfaction was taken as a mediating variable between motivation and job performance, and it also indicated a reduced $\beta$ $=.26$ to .24 . with a p-value from .02 to .03 . This significant value indicates that job satisfaction partially arbitrates the relationship between motivation and job performance; hence, $\mathrm{H}_{7}$ is also accepted. Table 5 presents the results of hypothesis testing.

Table 5

Examining the Hypotheses

\begin{tabular}{|c|c|c|c|c|c|}
\hline Hypothesis & Constructs & Estimate & Critical ratio & p-Value & Decision \\
\hline $\mathbf{H}_{1}$ & Mot. $\rightarrow$ Emp. Job Perf. & .29 & 2.94 & $.012^{*}$ & Accepted \\
\hline $\mathrm{H}_{1 \mathrm{a}}$ & Mot. $\rightarrow$ Task Perf. & .27 & 2.88 & $.023^{*}$ & Accepted \\
\hline $\mathrm{H}_{1 b}$ & Mot. $\rightarrow$ Cont. Perf. & .22 & 2.79 & $.026^{*}$ & Accepted \\
\hline $\mathrm{H}_{1 \mathrm{c}}$ & Ext. Mot. $\rightarrow$ Emp. Job Perf. & .21 & 1.99 & .038 & Accepted \\
\hline $\mathrm{H}_{1 \mathrm{~d}}$ & Ext. Mot. $\rightarrow$ Task Perf. & .27 & 2.78 & .019 & Accepted \\
\hline $\mathrm{H}_{1 \mathrm{e}}$ & Ext. Mot. $\rightarrow$ Cont. Perf. & .10 & 1.00 & .512 & Rejected \\
\hline $\mathrm{H}_{1 \mathrm{f}}$ & Int. Mot. $\rightarrow$ Emp. Job Perf. & .22 & 2.68 & .027 & Accepted \\
\hline $\mathrm{H}_{1 \mathrm{~g}}$ & Int. Mot. $\rightarrow$ Task Perf. & .18 & 1.99 & .041 & Accepted \\
\hline $\mathrm{H}_{1 \mathrm{~h}}$ & Int. Mot. $\rightarrow$ Cont. Perf. & .11 & 1.01 & .502 & Rejected \\
\hline $\mathbf{H}_{2}$ & Rew $\rightarrow$ Emp. Job Perf. & .23 & 2.91 & $.019^{*}$ & Accepted \\
\hline $\mathrm{H}_{2 \mathrm{a}}$ & Rew $\rightarrow$ Task Perf. & .31 & 3.13 & $.006^{* *}$ & Accepted \\
\hline $\mathrm{H}_{2 \mathrm{~b}}$ & Rew $\rightarrow$ Cont. Perf. & .26 & 2.63 & $.029^{*}$ & Accepted \\
\hline $\mathrm{H}_{2 \mathrm{c}}$ & Ext. Rew. $\rightarrow$ Emp. Job Perf. & .21 & 2.13 & $.041^{*}$ & Accepted \\
\hline $\mathrm{H}_{2 \mathrm{~d}}$ & Ext. Rew. $\rightarrow$ Task Perf. & .22 & 2.28 & $.036^{*}$ & Accepted \\
\hline $\mathrm{H}_{2 \mathrm{e}}$ & Ext. Rew. $\rightarrow$ Cont. Perf. & .20 & 2.11 & $.039^{*}$ & Accepted \\
\hline $\mathrm{H}_{2 \mathrm{f}}$ & Int. Rew. $\rightarrow$ Emp. Job Perf. & .20 & 2.61 & $.039^{*}$ & Accepted \\
\hline $\mathrm{H}_{2 \mathrm{~g}}$ & Int. Rew. $\rightarrow$ Task Perf. & .29 & 3.00 & $.008^{* *}$ & Accepted \\
\hline $\mathrm{H}_{2 \mathrm{~h}}$ & Int. Rew. $\rightarrow$ Cont. Perf. & .26 & 2.94 & $.017^{*}$ & Accepted \\
\hline $\mathbf{H}_{3}$ & Rew. $\rightarrow$ Job Sat. & .29 & 3.00 & .005 & Accepted \\
\hline $\mathrm{H}_{3 \mathrm{a}}$ & Ext. Rew. $\rightarrow$ Job Sat. & .27 & 2.97 & .009 & Accepted \\
\hline $\mathrm{H}_{3 \mathrm{~b}}$ & Int. Rew. $\rightarrow$ Job Sat. & .25 & 2.45 & .034 & Accepted \\
\hline $\mathbf{H}_{4}$ & Mot. $\rightarrow$ Job Sat. & .26 & 2.75 & .021 & Accepted \\
\hline $\mathrm{H}_{4 \mathrm{a}}$ & Ext. Mot. $\rightarrow$ Job Sat. & .22 & 2.31 & .039 & Accepted \\
\hline $\mathrm{H}_{4 \mathrm{~b}}$ & Int. Mot. $\rightarrow$ Job Sat. & .19 & 2.00 & .047 & Accepted \\
\hline H5 & Job Sat. $\rightarrow$ Emp. Job Perf. & .29 & 3.00 & .003 & Accepted \\
\hline $\mathrm{H}_{5 \mathrm{a}}$ & Job Sat. $\rightarrow$ Task Perf. & .26 & 2.27 & .012 & Accepted \\
\hline $\mathrm{H}_{5 \mathrm{~b}}$ & Job Sat. $\rightarrow$ Cont. Perf. & .20 & 2.22 & .034 & Accepted \\
\hline \multirow[t]{3}{*}{$\mathbf{H}_{6}$} & Rew. $\rightarrow$ Job Sat. & .21 & 2.21 & .031 & \multirow{3}{*}{ Accepted } \\
\hline & Rew. $\rightarrow$ Emp. Perf. & .20 & 2.27 & .026 & \\
\hline & Job Sat. $\rightarrow$ Emp. Perf. & .24 & 2.32 & .037 & \\
\hline \multirow[t]{3}{*}{$\mathbf{H}_{7}$} & Mot. $\rightarrow$ Job. Sat. & .24 & 2.54 & .035 & \multirow{3}{*}{ Accepted } \\
\hline & Mot. $\rightarrow$ Emp. Perf. & .55 & 2.55 & .027 & \\
\hline & Job. Sat. $\rightarrow$ Emp. Perf. & .53 & 2.45 & .029 & \\
\hline
\end{tabular}

Note. ${ }^{*} p \leq .05 ; * * p \leq .01$; Mot= Motivation; Emp. Per.= Employees Performance; Task Perf.=Task Performance; Cont. Perf.= Contextual Performance; Rew. $=$ Reward; Int. Rew. $=$ Intrinsic reward; Ext. Rew. $=$ Extrinsic Reward. 


\section{Discussion}

This research examined the role of motivation and reward in employee job satisfaction, leading to their job performance. As per the structural analysis, motivation has a significant positive impact on employee job performance. This means that motivation is one of the main sources for enhancing employees' efficiency and productivity and enhancing individual and organizational capacity to achieve desirable goals. This finding is consistent with Riyanto, Sutrisno, and Ali's (2017) study, which found a similar impact of motivation on employees' commitment levels and productivity. Motivation helps an employee in self-development and reaching its personal goals, which ultimately facilitate the organization to achieve its short and long-term goals. Thus, managers must motivate their employees and take it as a major orientation for employees' effective performance.

The path analysis also pointed out a significant positive impact of rewards on workers' job performance. Rewards play a critical role in enhancing workers' morale to put maximum effort into the best results and their firm's growth. This finding supports Martono, Khoiruddin, and Wulansari's (2018) conclusion that rewards play an essential resource in any organization's employee output. Management uses incentives to inspire their workers for their goal achievement. Also, effectively designing incentives programs can attract new talent for organizations and motivate current employees to meet high work standards with more efficiency. Desirable behaviors from the employees are required to attain their basic goals, which rely on how HR management of an organization has designed rewards and incentives policies to promote and recognize high performers at the workplace.

The examination of the relationship between rewards and job satisfaction also specified a considerable positive. This confirms the findings of Danish and Usman (2010) but contradicts Mahmood et al.'s (2014) results. Similarly, testing motivation and job satisfaction also presented significant positive results. This means that if firms want to enhance the satisfaction level of their employees, motivation and reward can play a key role in this regard. Moreover, the sampled firms are adequately benefiting from this approach.

Following this, the authors studied the effect of job satisfaction on employee job performance which presented significant positive results. This significant result is that a satisfied employee performs better than the non-satisfied one. This also means that the management of the sampled firms are taking adequate measures to strengthen the satisfaction level of their employees so that they perform their tasks with great zeal to deliver their maximum performance. This finding relates to the study of Danish and Usman (2010) and Mahmood et al. (2020) that a satisfied employee tends to perform better than the opposite one.

To examine these variables more comprehensively, the authors performed a dimensional analysis. Each dimension of motivation and reward was examined with each dimension of the job performance. The dimensional analysis indicated a positive impact of all studied dimensions given in Table 5, except the intrinsic and extrinsic motivation effect on the contextual performance of employees. Although the analysis indicated a positive impact, the p-values exceed the acceptable range. This means that the management of the studied organizations needs to intrinsically and extrinsically motivate their employees to maximize their performance. This study shows that motivation and rewards are among the most effective tools that managers can use to increase their employees' morale and help them make their organizational culture healthier and productive. 


\section{Implications}

The results of the current study can be quite beneficial for organizational managers and supervisors. The empirical results prove that motivation and a fair reward system (i.e., intrinsic and extrinsic) play a favorable role in amplifying the employees' performance at the workplace. The managers need to ensure that people working under their supervision are happy and satisfied. Setting objectives is not just enough; telling and leading them to drive their desirable behaviors that promote their high performance is essential. Motivation can play a critical role in augmenting the productivity of employees. Managers can achieve this by giving small favors, incentives, bonuses, appreciation, or even a small word of praise. Organizations should implement a variety of rewards and recognition programs and motivational tactics to make their employees motivated and dedicated so they can achieve their desired goals with more efficiency and effectiveness.

The results also showed that financial rewards (extrinsic) are responsible for satisfaction at the workplace. The non-monetary (intrinsic) incentives are also a major source of job satisfaction and employees' improved performance. Therefore, the HR department needs to make sure that employees are rewarded in fiscal compensations like appraisals and bonuses and make sure employees' intrinsic needs are also kept in mind. A fiscal reward might not keep every employee motivated and directed to the organizational vision. Therefore, it is the major responsibility of management to motivate and reward all employees according to their needs so that their satisfaction can be ensured, which eventually will lead towards the attainment of organizational goals.

\section{Limitations}

The study had its limitations as well. The fairly low number of respondents is one of the study's major limitations. Even though the results found are significant and considerable, but the moderate size of the sample is expected to lack the component of generalizability. Along with that, due to lack of time and resources, the authors focused only on three main cities of Pakistan, i.e., Islamabad, Lahore, and Karachi, which are not providing the complete representation of the whole region. Therefore, it is recommended that future research broaden its scope by increasing its sample size and considering other regions. Considering the important role of the demographic aspect, it is suggested to take employee experience and his position as the control variable and investigate whether these variables significantly impact the studied variables.

Another limitation of this research is that only two perspectives (i.e., motivation and rewards system) are considered to see how they can bring desirable behaviors of the employees in terms of job satisfaction and job performance. Researchers in the future should also consider other factors, such as organizational culture, management styles, etc., that can affect employee performance. In addition, the mediatory effect of gender roles can also shift the research results while studying the effect of extrinsic and intrinsic motivation on employees' performance.

The responses of top management were far less; taking their more opinions can create better future insights to understand this phenomenon of research. The covered organizations were mainly part of the services and manufacturing industry located in Pakistan; thus, it should be borne in mind that the results may not be generalized to all the industries of Pakistan. Therefore, if a similar study is carried out in the future, it is suggested that mixed business sectors be examined to better understand the given research model. 


\section{Conclusion}

This paper's primary focus is to study the effects of motivation and intrinsic and extrinsic rewards on employees' job satisfaction and job performance by building its arguments on selfdetermination theory. The researchers used a non-probability convenience sampling method for data collection and the SEM technique for data analysis. This research showed a significant favorable impact of motivation and rewards on employee performance. Additionally, it has also been proved that where financial rewards play the most important role in motivating employees, at the same time, intrinsic motivation has a significant effect on employee's productivity. Therefore, the findings of the research support those informal recognitions such as (well done, excellent performance, thank you) also motivate the employees in improving their performance. Likewise, if the managers are inclined to listen and understand their employees' different perspectives and preferences, they will inevitably feel inner satisfaction at the workplace. Correspondingly, when employees feel satisfied with their employment, they will eventually continue to give excellent performance at the workplace.

\section{References}

Abbas, J., Alturki, U., Habib, M., Aldraiweesh, A., \& Al-Rahmi, W. M. (2021). Factors affecting students in the selection of country for higher education: A comparative analysis of international students in Germany and the UK. Sustainability, 131(65), 1-17. https://doi.org/10.3390/su131810065

Abbas, J., \& Kumari, K. (2021). Examining the relationship between total quality management and knowledge management and their impact on organizational performance. Journal of Economics and Administrative Sciences. Ahead-ofprint. https://doi.org/10.1108/JEAS-03-2021-0046

Abbas, J., \& Sagsan, M. (2019). Identification of key employability attributes and evaluation of university graduates' performance: Instrument development and validation. Higher Education, Skills and Work-Based Learning, 10(3), 449466. https://doi.org/10.1108/HESWBL-06-2019-0075

Admassie, G. A. (2019). Impact of rewards management system on employees' satisfaction in case of DebreBirhan University Administrative Staffs. Journal of Investment and Management, 8(1), 16-24.

Aguinis, H., \& Burgi-Tian, J. (2021). Talent management challenges during COVID-19 and beyond: Performance management to the rescue. Business Research Quarterly, 24(3), 233-240.

Ahsan, M. U., Nasir, M., \& Abbas, J. (2020). Examining the causes of plastic bags usages and public perception about its effects on the natural environment. International Journal of Academic Research in Business and Social Sciences, 10(10), 80-96. http://dx.doi.org/10.6007/IJARBSS/v10-i10/7919

Aizza, A. W., Shakeel, K., \& Hassan, S. S. (2018). Impact of intrinsic and extrinsic motivation on Employee's retention: A case from call center. International Journal of Academic Research in Business and Social Sciences, 8(6), 652-666.

Al-Ali, W., Ameen, A., Isaac, O., Khalifa, G. S., \& Shibami, A. H. (2019). The mediating effect of job happiness on the relationship between job satisfaction and employee performance and turnover intentions: A case study on the oil and gas industry in the United Arab Emirates. Journal of Business and Retail Management Research, 13(4), 103-116.

Alhmoud, A., \& Rjoub, H. (2020). Does generation moderate the effect of total rewards on employee retention? Evidence from Jordan. SAGE Open, 10(3), 2158244020957039.

Ali, B. J., \& Anwar, G. (2021). An empirical study of employees' motivation and its influence job satisfaction. International Journal of Engineering, Business and Management, 5(2), 21-30.

Alsafadi, Y., \& Altahat, S. (2021). Human resource management practices and employee performance: The role of job satisfaction. The Journal of Asian Finance, Economics, and Business, 8(1), 519-529.

Alshmemri, M., Shahwan-Akl, L., \& Maude, P. (2017). Herzberg's two-factor theory. Life Science Journal, 14(5), 12-16.

Awang, Z. (2012). A handbook on structural equation modeling using AMOS. Kota Baru Universiti Teknologi Mara Kelantan.

Anwar, G., \& Abdullah, N. N. (2021). The impact of Human resource management practice on Organizational performance. International Journal of Engineering, Business and Management (IJEBM), 5. 
Ayub, N., \& Rafif, S. (2011). The relationship between work motivation and job satisfaction. Pakistan Business Review, 13(2), 332-347.

Badura, K. L., Grijalva, E., Galvin, B. M., Owens, B. P., \& Joseph, D. L. (2020). Motivation to lead: A meta-analysis and distal-proximal model of motivation and leadership. Journal of Applied Psychology, 105(4), 331.

Bagozzi, R., \& Yi, Y. (1988). On the evaluation of structural equation models. Journal of the Academy of Marketing Science, 16(1), 74-94.

Bao, H. J., Cheng, H. K., Vejayaratnam, N., Anathuri, A., Seksyen, S., Bangi, B. B., \& Bakar, A. A. (2021). A study on human resource function: recruitment, training and development, performance appraisal and compensation. Journal of Global Business and Social Entrepreneurship (GBSE), 7(20).

Baughman, R. (2018). Employment in long-term care: The role of macroeconomic conditions. The B.E. Journal of Economic Analysis \& Policy, 18(4).

Bayraktar, C. A., Araci, O., Karacay, G., \& Calisir, F. (2017). The mediating effect of rewarding on the relationship between employee involvement and job satisfaction. Human Factors and Ergonomics in Manufacturing \& Service Industries, 27(1), 45-52.

Bentler, P. M., \& Bonett, D. G. (1980). Significance tests and goodness of fit in the analysis of covariance structures. Psychological Bulletin, 88(3), 588-606.

Blau, P. (1964). Exchange and power in social life. New York: John Wiley \& Sons.

Bollen, K. A. (1986). Sample size and Bentler and Bonett's Nonnormed fit index. Psychometrika, 51(3), 375-377.

Brayfield, A. H., \& Crockett, W. H. (1955). Employee attitudes and employee performance. Psychological Bulletin, 52(5), 396-424. https://doi.org/10.1037/h0045899

Breaugh, J., Ritz, A., \& Alfes, K. (2018). Work motivation and public service motivation: Disentangling varieties of motivation and job satisfaction. Public Management Review, 20(10), 1423-1443.

Browne, M. W., \& Cudeck, R. (1992). Alternative ways of assessing model fit. Sociological Methods \& Research, 21(2), $230-258$.

Campbell, J. P., \& Wiernik, B. M. (2015). The modeling and assessment of work performance. Annual Review of Organizational Psychology and Organizational Behavior, 2(1), 47-74.

Catharina, T., \& Victoria, V. (2015). The impact of extrinsic and intrinsic motivation towards job satisfaction in finance service department of PT. XYZ. IBuss Management, 3(2).

Danish, R. Q., \& Usman, A. (2010). Impact of reward and recognition on job satisfaction and motivation: An empirical study from Pakistan. International Journal of Business and Management, 5(2), 159-167. https://doi.org/10.5539/ijbm.v5n2p159

Deci, E. L., \& Ryan, R. M. (1985). The general causality orientations scale: Self-determination in personality. Journal of Research in Personality, 19(2), 109-134.

Din, G. R. A., Shahani, N. U. N., \& Baloch, M. N. (2021). Impact of rewards system in employee's motivation in the organizational context: A quantitative study of manufacturing industry in UAE. Liberal Arts and Social Sciences International Journal (LASSIJ), 5(1), 105-122. https://doi.org/10.47264/idea.lassij/5.1.8

Fanggidae, R. E., Nursiani, N. P., \& Bengngu, A. (2019). The influence of reward on organizational commitment towards spirituality workplace as a moderating variable. Journal of Management and Marketing Review, 4(4), 260-269.

Febrianti, N. T., \& SE, S. (2020). The effect of career development and motivation on employee performance through job satisfaction in Pt Jabar Jaya Perkasa. International Journal of Business and Social Science Research, 1(2).

Fornell, C., \& Larcker, D. F. (1981). Evaluating structural equation models with unobservable variables and measurement error. Journal of Marketing Research, 18(1), 39-50. https://doi.org/10.1177/002224378101800104

Ghazi, S. R., Shahzada, G., \& Khan, M. S. (2013). Resurrecting Herzberg's two factor theory: An implication to the university teachers. Journal of Educational and Social Research, 3(2), 445-445.

Gift, R., \& Obindah, F. (2020). Examining the influence of motivation on organizational productivity in Bayelsa state private hospitals. Open Access Journal of Science, 4(3), 94-108.

Guilbault, M. (2018). Students as customers in higher education: The (controversial) debate needs to end. Journal of Retailing and Consumer Services, 40(1), 295-298.

Guo, Y., \& Ling, B. (2020). Effects of leader motivating language on employee task and contextual performance: The mediating role of feedback quality. Psychological Reports, 123(6), 2501-2518.

Habib, M., Abbas, J., \& Noman, R. (2019). Are human capital, intellectual property rights, and research and development expenditures really important for total factor productivity? An empirical analysis. International Journal of Social Economics, 46(6), 756-774. https://doi.org/10.1108/IJSE-09-2018-0472 
Hair, J. F., Sarstedt, M., Ringle, C. M., \& Mena, J. A. (2012). An assessment of the use of partial least squares structural equation modeling in marketing research. Journal of the Academy of Marketing Science, 40(3), 414-433.

Hair, Jr., J. F., Black, W. C., Babin, B. J., \& Anderson, R. E. (2010). Multivariate data analysis a global perspective (7th ed.). Pearson.

Hammond, H. G., \& Waltemeyer, S. (2021). Policies and procedures that may hinder morale, motivation, and engagement. In Handbook of research on inclusive development for remote adjunct faculty in higher education (pp. 233-252). IGI Global.

Hamza, P. A., Othman, B. J., Gardi, B., Sorguli, S., Aziz, H. M., Ahmed, S. A., ... Anwar, G. (2021). Recruitment and selection: The relationship between recruitment and selection with organizational performance. International Journal of Engineering, Business and Management, 5(3), 1-13.

Herzberg, F. (1964). The motivation-hygiene concept and problems of manpower. Personnel Administration, 27, 3-7.

Hidayat, K. C. (2019). The effect of extrinsic rewards and intrinsic rewards towards motivation and job performance of employees in DKI Jakarta Are (Doctoral dissertation). Sekolah Tinggi Manajemen IPMI.

Hinkin, T. R. (1998a). A brief tutorial on the development of measures for use in survey questionnaires. Organizational Research Methods, 1(1), 104-121.

Hosie, P., \& Nankervis, A. (2016). A multidimensional measure of managers' contextual and task performance. Personnel Review, 45(2), 419-447. https://doi.org/10.1108/PR-02-2014-0038

Hu, L., \& Bentler, P. M. (1998). Cutoff criteria for fit indexes in covariance structure analysis: Conventional criteria versus new alternatives. Structural Equation Modeling: a Multidisciplinary Journal,6(1), 1-55.

Hünefeld, L., Gerstenberg, S., \& Hüffmeier, J. (2020). Job satisfaction and mental health of temporary agency workers in Europe: A systematic review and research agenda. Work \& Stress, 34(1), 82-110.

Hussain, S. D., Khaliq, A., Nisar, Q. A., Kamboh, A. Z., \& Ali, S. (2019). The Impact of employees' recognition, rewards and job stress on job performance: Mediating role of perceived organization support. SEISENSE Journal of Management, $2(2), 69-82$.

Ibrar, M., \& Khan, O. (2015). The impact of reward on employee performance (a case study of Malakand private school). $52,95-103$.

Idris, I., Adi, K. R., Soetjipto, B. E., \& Supriyanto, A. S. (2020). The mediating role of job satisfaction on compensation, work environment, and employee performance: Evidence from Indonesia. Entrepreneurship and Sustainability Issues, $8(2), 735-750$.

Imran, M., \& Abbas, J. (2020). The role of strategic orientation in export performance of China automobile industry. In Handbook of Research on Managerial Practices and Disruptive Innovation in Asia (pp. 249-263). IGI Global.

Jeni, F. A., Mutsuddi, P., \& Das, S. (2020). The impact of rewards on employee performance: a study of commercial banks in Noakhali Region. Journal of Economics, Management and Trade, 26(9), $28-43$. https://doi.org/10.9734/jemt/2020/v26i930289

Kaiser, H. F., \& Rice, J. (1974). Little jiffy, mark IV. Educational and Psychological Measurement, 34(1), 111-117.

Kaynak, H. (2003). The relationship between total quality management practices and their effects on firm performance. Journal of Operations Management, 21(4), 405-435.

Kazmi, S. J. A., \& Abbas, J. (2021). Examining the impact of industry 4.0 on labor market in Pakistan. In Handbook of Smart Materials, Technologies, and Devices (pp. 1-11). Switzerland: Springer.

Koralege, J., \& Priyashantha, K. (2019). Impact of rewards on individual job performance: with special reference to vogue tex (Pvt.) Ltd.

Kumar, N., \& Singh, V. (2011). Job satisfaction and its correlates. International Journal of Research in Economics \& Social Sciences, 1(2), 11-24.

Kumar, R. (1996). Research methodology: A step by step guide for beginners. Melbourne, Australia: Addison Wesley Longman Publishers.

Liu, Y., Hassan, M., Chupradit, S., Ageli, M., Shoukry, A. M., \& Aldeek, F. F. (2021). Aggressive workplace behavior, motivation, and worker's output: Mediating effect of religiosity among the service sector employees. Aggression and Violent Behavior, 101625.

Mahmood, H. K., Hashmi, M. S., Shoaib, D. M., Danish, R., \& Abbas, J. (2014). Impact of TQM practices on motivation of teachers in secondary schools empirical evidence from Pakistan. Journal of Basic and Applied Scientific Research, 4(6), $1-8$.

Mahmood, H. K., Hussain, F., Mahmood, M., Kumail, R., \& Abbas, J. (2020). Impact of e-assessment at middle school students' learning - an empirical study at USA middle school students. International Journal of Scientific \& Engineering Research, 11(4), 1722-1736. 
Martono, S., Khoiruddin, M., \& Wulansari, N. A. (2018). Remuneration reward management system as a driven factor of employee performance. International Journal of Business \& Society, 19(S4), 535-545.

Maslow, A. H. (1943). A theory of human motivation. Psychological Review, 50(4), 370-396.

Mazllami, A. (2020). The impact of rewards on employee performance: In SMEs in Polog region. economic visionInternational Scientific Journal in Economics, Finance, Business, Marketing, Management and Tourism, 7(13-14), 5362.

McDonald, R. P., \& Marsh, H. W. (1990). Choosing a multivariate model: Noncentrality and goodness of fit. Psychological Bulletin, 107(2), 247-255.

Mikander, C. (2010). The impact of a reward system on employee motivation in Motonet-Espoo. Arcada.

Mohammad, J. U., Miah, M. A. S., Rahman, M. M., \& Rahaman, M. S. (2017). Mediation role of job satisfaction on HRMoperational performance relationship: A three-way moderation effect by gender. The Journal of Developing Areas, 51(3), $437-452$.

Molina, L. M., Montes, J. L., \& Moreno, A. R. (2007). Relationship between quality management practices and knowledge transfer. Journal of Operations Management, 25(3), 682-701.

Muchiri, H. (2016). Effects of rewards on employee performance in the hospitality indusTRY: A case of Nairobi Serena Hotel. Africa: United States International University.

Nazir, S., Shafi, A., Qun, W., Nazir, N., \& Tran, Q. D. (2016). Influence of organizational rewards on organizational commitment and turnover intentions. Employee Relations, 38(4), 596-619. https://doi.org/10.1108/ER-12-2014-0150

Nguyen, P. T., Arifani, A. Z. T., Susanti, A. Y., \& Mahaputra, M. R. (2020). Literature review factors affecting employee performance: Competence, compensation and leadership. Dinasti International Journal of Economics, Finance \& Accounting, 1(3), 538-549.

Ngwa, W. T., Adeleke, B. S., Agbaeze, E. K., Ghasi, N. C., \& Imhanrenialena, B. O. (2019). Effect of reward system on employee performance among selected manufacturing firms in the Litoral region of Cameroon. Academy of Strategic Management Journal, 18(3), 1-16.

Nyinyimbe, S. E. (2020). The impact of employees motivation on organization effectiveness a case study of the National Social Security Fund (NSSF) at Kinondoni district. COSTECH Integrated Repository. Retrieved from http://hdl.handle.net/11192/3792

Omokorede, \& Olufunke, A. (2017). Reward system and employee performance of selected manufacturing companies in Lagos State, Nigeria. Babcock University Ilishan-Remo Ogun State Nigeria.

Ouedraogo, A., \& Leclerc, A. (2013). Job satisfaction and organizational performance: Evidence from Canadian credit union. Journal of Organizational Culture, Communications and Conflict, 17(1), 35-50.

Özutku, H. (2019). The Influence of intrinsic and extrinsic rewards on employee results: An empirical analysis in Turkish manufacturing industry. Business and Economics Research Journal, 3(3), 29-48.

Paais, M., \& Pattiruhu, J. R. (2020). Effect of motivation, leadership, and organizational culture on satisfaction and employee performance. The Journal of Asian Finance, Economics, and Business, 7(8), 577-588.

Parashakti, R. D., \& Ekhsan, M. (2020). The effect of discipline and motivation on employee performance in PT Samsung Elektronik Indonesia. Journal of Business, Management, \& Accounting, 2(3), 653-660.

Peterson, R. A. (1994). A Meta-analysis of Cronbach's Coefficient Alpha. Journal of Consumer Research, 21(2), 381-391.

Podsakoff, P. M., MacKenzie, S. B., \& Podsakoff, N. P. (2012). Sources of method bias in social science research and recommendations on how to control it. Annual Review of Psychology, 63, 539-569.

Prajogo, D. I., \& Cooper, B. K. (2010). The effect of people-related TQM practices on job satisfaction: A hierarchical model. Production Planning \& Control: The Management of Operations, 21(1), 26-35.

Prasetiyani, D., Kristianti, L. S., Andi, D., \& Abid, M. (2021). The effect of rewards and motivation on employee productivity at PT. Sinar Kencana Jaya in Surabaya, 1(1), 43-47.

Rehman, M., Ilyas, M., \& Saqib, A. (2017). Role of rewards to foster knowledge sharing practices: Mediating role of psychological commitment. Pakistan Business Review, 19(2), 465-480.

Riyanto, S., Sutrisno, H., \& Ali, H. A. (2017). The impact of working motivation and working environment on employees performance in Indonesia stock exchange. International Review of Management and Marketing, 7(3), 342-348.

Ryan, R. M., \& Deci, E. L. (2020). Intrinsic and extrinsic motivation from a self-determination theory perspective: Definitions, theory, practices, and future directions. Contemporary Educational Psychology, 61, 101860.

Saengchai, S., Siriattakul, P., \& Jermsittiparsert, K. (2019). Exploring the link between HR practices, employee motivation, employee empowerment and employee performance in engineering firms of Indonesia. International Journal of Psychosocial Rehabilitation, 23(4), 734-748. 
Safdar, B., Habib, A., Amjad, A., \& Abbas, J. (2020). Treating students as customers in higher education institutions and its impact on their academic performance. International Journal of Academic Research in Progressive Education and Development, 9(4), 176-191.

Sekaran, U., \& Bougie, R. (2003). Research methods for business: A skill building approach. New York: John Willey \& Sons. Inc.

Shaikh, S. H., Shaikh, H., \& Shaikh, S. (2019). The impact of job satisfaction and job dissatisfaction on Herzberg theory: A case study of Meezan Bank Limited and National Bank Limited. International Journal of Business and Social Science, 10(6), 143-147.

Shakoor, F., Fakhar, A., \& Abbas, J. (2021). Impact of smartphones usage on the learning behaviour and academic performance of students: Empirical evidence from Pakistan. International Journal of Academic Research in Business and Social Sciences, 11(2), 862-881.

Skinner, B. F. (2014). Contingencies of reinforcement: A theoretical analysis (Vol. 3). BF Skinner Foundation.

Sureephong, P., Dahlan, W., Chernbumroong, S., \& Tongpaeng, Y. (2020). The effect of non-monetary rewards on employee performance in massive open online courses. International Journal of Emerging Technologies in Learning, 15(1), 88-102.

Tajeddini, K., Martin, E., \& Altinay, L. (2020). The importance of human-related factors on service innovation and performance. International Journal of Hospitality Management, 85, 102431.

Tian, A. Y., Ahammad, M. F., Tarba, S. Y., Pereira, V., Arslan, A., \& Khan, Z. (2021). Investigating employee and organizational performance in a cross-border acquisition-A case of withdrawal behavior. Human Resource Management, 60(5), 753-769.

Triswanto, H., \& Yunita, L. (2021). The Influence of intrinsic motivation and extrinsic motivation on employee performance productivity of PT. Weigh Deli Indonesia. Journal of Economics and Business (JECOMBI), 1(2), 155-161.

Willsen, W. (2020). The influence of incentive and rewards towards employee performance at The Traders Restaurant Medan (Unpublished doctoral dissertation). Universitas Pelita Harapan.

Wolomasi, A. K., Asaloei, S. I., \& Werang, B. R. (2019). Job Satisfaction and Performance of Elementary School Teachers. International Journal of Evaluation and Research in Education, 8(4), 575-580.

Yadav, P., \& Singh, B. (2021). The Impact of Effective Recruitment \& Selection Process on Organizational Development: An Empirical Study. Annals of the Romanian Society for Cell Biology, 25(6), 693-703.

Yang, Y., \& Ai, X. (2020). An Empirical Study on Relationship between Rewards and Employee Creativity in Advertising Agencies: Motivation as a Mediator. Proceedings of the 4th International Conference on Innovation in Artificial Intelligence (pp. 205-210).

Yousaf, A., Yang, H., \& Sander, K. (2015). Effects of intrinsic and extrinsic motivation on task and contextual performance of Pakistani professionals: The mediating role of commitment. Journal of Managerial Psychology, 30(2), 133-150.

Yousuf, S., \& Siddiqui, D. A. (2019). Factors influencing employee retention: A Karachi based comparative study on IT and banking industry. International Journal of Human Resource Studies, 9(1), 42-62.

Zafar, N., Ishaq, S., Shoukat, S., \& Rizwan, M. (2014). Determinants of employee motivation and its impact on knowledge transfer and job satisfaction. International Journal of Human Resource Studies, 4(3), 50-69.

Zainal, H. (2017). Influence of work motivation and discipline on work productivity. Proceedings of the 2nd International Conference on Education, Science, and Technology, 149, 25-27. https://doi.org/10.2991/icest-17.2017.9

\section{Acknowledgements}

The authors are thankful to all the individuals who directly or indirectly contributed to this manuscript's completion.

\section{Disclosure Statement}

No potential conflict of interest was reported by the authors.

\section{Funding Acknowledgements}

Not applicable.

\section{Open Access}

The International Journal of Organizational Leadership publishes open access articles under the terms of the Creative Commons Attribution (CC BY) License, which permits use, distribution, and reproduction in any medium, provided the original work is properly cited. 